industrial firms might, it is suggested, take the shape of some kind of voluntary levy. One of the earliest tesks of the Board would be the planning of scientific research on a comprehensive scale. Research associations could be increased to cover all industries and might be grouped under research boards, following the example of the present Iron and Steel Research Board. In addition, it is suggested that a number of institutes for studying the fundamental aspects of applied research might be set up. It is not claimed that this proposed scheme for the endowment of science is more than a first draft, and the publication of the present proposals is intended in the first place to stimulate discussion, from which it may be hoped alternative, better balanced and more comprehensive schemes might emerge.

\section{Drift of the Soviet Polar Station}

DURING the last week, the drift of the Soviet Polar Station has become more rapid and on several days was as much as thirty miles. On February 11 the station was in lat. $71^{\circ} 48^{\prime} \mathrm{N}$., long. $19^{\circ} 52^{\prime} \mathrm{W}$., and within sight of the coast of East Greenland. The Times reports that the Danish authorities have sent instructions to Danes and Eskimos at the settlement at Scoresby Sound to arrange food depots along the coast in case the Russians decide that the only possible retreat is to cross the ice stream to the land. The men are now living in a snow hut, but so long as the ice stream remains compact they are in no immediate danger. Their greatest risk lies in the probability of the pack spreading and the floes being dispersed and destroyed farther south. Moreover, the southern part of East Greenland is very rugged and has no inhabitants or food depots south of Angmagsalite. If the men have to cross the ice stream to land, it is unlikely that they will be able to carry much with them. The icebreaker Yermak left Leningrad on February 11 and should be off the east coast about February 19. She has on board an autogyroplane, by which it is hoped a landing on a floe of restricted size will be possible. The last reports available were to the effect that the Taimir and the Murman are in constant telephonic communication with the men, but that a storm on February 14 had prevented an aerodrome being formed on the ice from which an aeroplane might start to rescue them.

\section{Experimental Flights Across the Atlantic}

THE recent successful separation in the air of the seaplane Mercury from the flying boat Maia directs attention to the experimental work upon the matter of long-distance flights with commercial aircraft that is proceeding in readiness for the resumption of the Atlantic crossings during the coming summer. This combination, known as the Mayo Composite or "Pickaback" aircraft, built by Messrs. Short Bros. of Rochester, is an attempt to get a seaplane into the air with a wing loading that is prohibitively high for normal take-off, but is practicable for flight when once in the air at a safe height. The upper component is a heavily loaded seaplane that carries out the actual flight. This is carried on top of a comparatively lightly loaded fiying boat capable of taking off and climbing easily and safely. When at about 5,000 feet the two separate, parting rapidly in a vertical plane, without risk of fouling or subsequent collision. Another method of attacking this problem is for the machine to start with a minimum of fuel, then sufficiently lightly loaded for safe takeoff, and take on its full load of petrol from a tanker aircraft while in the air. Messrs. Imperial Airways, in co-operation with $\mathrm{Sir}$ Alan Cobham, have been using one of the large Empire class flying boats, the Cambria, for tests upon this method, with satisfactory results so far as they have gone.

A THIRD method is to catapult the machine into the air, giving it the necessary minimum forward speed for flight by applying an impulse to it by some exterior mechanism, using hydraulic or explosive power. This, while possibly the simplest, is the least comfortable for the occupants of the aircraft. The R.A.F. have done considerable work on this, and it can be said to be successfully developed. In addition to these experiments, eight additional Empire type flying boats strengthened to carry $53,000 \mathrm{lb}$. instead of the normal $40,500 \mathrm{lb}$., have been ordered. These will have both greater fuel capacity and carry more useful load for such flights. Machines of the De Havilland "Albatross" class, a four-engined land machine specially designed for this work are also to be used.

\section{R.A.F. High-Speed Flight}

THE flight by Squadron Leader J. W. Gillan, on February 10, using a Hawker "Hurricane", a R.A.F. high-speed fighter machine, directs attention to the development that has taken place, both in speeds of modern aircraft and in the methods of navigation. While this was not a properly observed speed record, in the sense that it was timed with great accuracy and afterwards reduced to a speed relative to still air, it was an ordinary flight undertaken under practical conditions upon a standard machine, and should be repeatable, under reasonable weather conditions, as circumstances demand. The flight was made in darkness, leaving Turnhouse Aerodrome, Edinburgh, at 5.5 p.m., arriving at Northolt Aero. drome, London, at 5.53 p.m. The distance was 327 miles, giving an average speed of $408 \cdot 75$ miles an hour, assuming the course to have been the shortest distance between the two points. This speed was helped by a high following wind of at least 50 miles an hour, although not exactly a tail wind on the line of flight. The course was flown entirely blind by the use of instruments. The "Hurricane" is fully equipped in this respect, carrying directional gyroscope, turn indicator, artificial horizon, rate of climb indicator, and a sensitive altimeter. Actually it was a real test of this method of flying, as much of the flight was made through or above cloud entirely obscuring even such landmarks as would have been visible after dark. Also the windscreen was coated with ice at certain stages of the flight, a further hindrance to vision. The machine was climbed slowly to 17,000 
feet altitude, and maintained at that height until it was necessary to put it into a slow descent. This occurred over Bedford, one of the few towns that the pilot had been able to see through the clouds. He reported that he had been perfectly comfortable and warm, had had no occasion to use oxygen, and had no feeling of fatigue. The cockpit of this type of machine is entirely covered over with transparent cellulose material, and attention is paid to keeping the pilot warm.

\section{Film illustrating Movement of a Fœtus}

AT the meeting of the Royal Society held on February 10, Sir Joseph Barcroft and D. H. Barron showed a film illustrating the development of movement in the foetus of the sheep. The development of movement was depicted in respect of : $(a)$ the types of movement which appear at different fotal ages, and $(b)$ the individuation of certain sorts of purposive movement from a general mass movement. The period of gestation is about 145 days. Up to about 35 days, the foetus is immobile (type 1). At 35 days it commences to exhibit movements which are always 'jerky' (type 2). At 47-50 days it is almost incessant motion, which is 'sustained' (type 3). After 50 days the fotus becomes quiescent (type 4). The following analysis may be made of these types: If the spinal cord be cut just below the brain at 60 days, without taking the fotus out of the uterus, and the fotus be allowed to continue growing until the cut fibres have degenerated, its body will exhibit jerky movements (type 2), whilst its head is quiescent (type 2). If the central nervous system is transected below the pons, the whole fœetus exhibits jerky movements (type 4). If the central nervous system is sectioned above the red nucleus the foetus exhibits sustained movements (type 3). The mechanism for the integration of 'jerky' into 'sustained' movements is in the region of the red nucleus, and the mechanism for the inhibition of movement is preponderantly above that. Later parts of the film showed the development of respiratory movements (especially in relation to somatic movement), the development of progressive movement and the development of 'righting' movements.

\section{Development of Calcutta}

“The Second City of the Empire", compiled by Dr. P. C. Bagchi, has been published under the auspices of the Indian Science Congress Association as guide book and souvenir of its silver jubilee meeting recently held in Calcutta. The brochure, which is fully illustrated, gives a historical account of the rise and growth of this eity and describes the develop. ment of its municipal administration, educational, industrial, public and social services. Calcutta came into existence towards the end of the seventeenth century, and largely owing to its geographical position rapidly grew into an important town. According to the 1935 census, its population now numbers more than a million. The city is mainly industrial and commercial, textiles and tea being two of the chief commodities with which it is concerned. Rapid strides have been made in education during the last century, particularly since the foundation of the University in 1857. To illustrate the more modern developments on the medical side, mention may be made of the opening of the Pasteur Institute in 1924, and more recently still, the Institute of Hygiene and Public Health. The formation of the Vangiya Sahitya Parishad in 1894, for the cultivation and improvement of the Bengali language and literature, has done much to further the study of arts, while the Bose Research Institute, opened in 1917, is an example of the interest taken in pure scientific research.

\section{The Volta Temple at Como}

IN Engineering of January 7 and 21 and February 4, Mr. F. Walker gives an account of the beautiful Volta Temple at Como, erected as a permanent memorial. The erection of the Temple was made possible by the generosity of $\mathrm{Gr}$. Uff. ou Francesco Somaini, whose commission to the architect Signor Federico Frigerio placed no limits whatsoever on the class of work or expenditure involved. Standing in the public gardens near the edge of a lake in Como, the Temple is a white marble building in the NeoClassical style, measuring approximately $25 \mathrm{~m}$. in length, $20 \mathrm{~m}$. in depth and $21 \mathrm{~m}$. in height. The main building consists of a large circular hall surmounted by a dome, which is supported by four corner pilasters and eight marble columns. Above the capitals of the pillars is a cornice bearing in gold letters an inscription of dedication. A marble staircase leads to a mezzanuil gallery around the central rotunda, and on the parapet of the gallery are four sculptured panels illustrating incidents in Volta's life. One of these represents him demonstrating his pile to Napoleon at Paris. Though much of Volta's apparatus was destroyed in the fire at the Como Exhibition of 1899, his manuscripts and books were saved and replicas of his apparatus are shown in cases, together with many personal relics. The entire expense for the collection of apparatus has been borne by Signor Somaini, who has further endowed the Temple with a capital of 500,000 lire, the interest of which is to provide scholarships. $\mathrm{Mr}$. Walker's article is accompanied with many photographs of what appears to be the most remarkable monument to any man of science.

\section{Early Hittite Civilization in Cilicia}

REsults, which at first sight hold out great promise of additions to knowledge of the early stages in the extension of Hittite culture, have been obtained by the Neilson Expedition of the University of I iverpool under Prof. J. Garstang, now engaged in excavating an archæological site near Mersina on the Cilician coast of Asia Minor. A double-walled fortress has been discovered, which is thought to mark the site of a frontier post between the rival southern kingdom of Assawa and the allied State of Kizzuwadna (which seems to have included Tarsus) during the sixteenth or fifteenth century B.C., when the latter stage formed part of the realm of the Hatti, usually identified under the more familiar name of Hittites. According to a report of recent excavations (The Times, February 9), deep soundings on a con- 